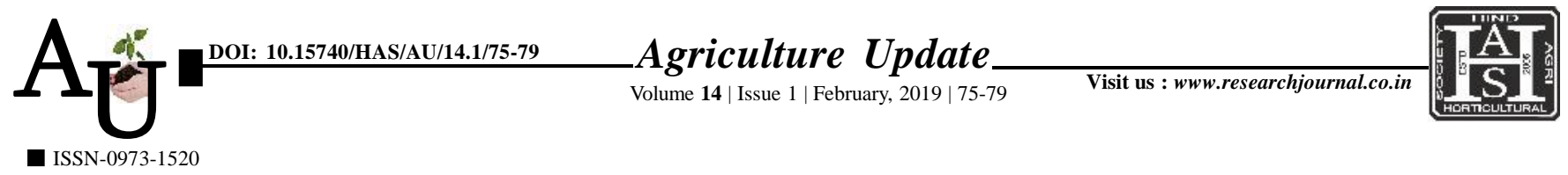

\title{
REsERсн ARтLLE: Management behaviour of the farmers in relation to improved cultivation of hybrid rice in Satna district (M.P.)
}

Toran Lal Nishad, Antim Birla, Sanjay Singh, Shilpi Singh and Azlan Khan

Article Chronicle:

Received :

28.11.2018;

Revised :

12.01.2019;

Accepted :

18.01.2019

KEY WoRds:

Hybrid rice,

Technology,

Management,

Farmers

Author for correspondence :

Toran Lal Nishad

Department of

Extension Education,

College of Agriculture

(J.N.K.V.V.), Rewa

(M.P.) India

Email: torannishad57@

gmail.com

See end of the article for

authors' affiliations
SUMMARY : Hybrid rice technology appears to be a feasible and readily available option for raising the yield potential. However, there is still scope for raising hybrid rice production in Satna district by adoption of recommended practices of hybrid rice by the All India Co-ordinated Rice Improvement Project (ICAR) College of Agriculture Rewa (M.P.). The present study was carried out in Satna district of Madhya Pradesh to assess management behaviour of the farmers in relation to improved cultivation of hybrid rice with a sample of 120 hybrid rice growers. The study revealed that among all the components of management behaviour of hybrid rice cultivation in highest mean score was observed in technology management (1.35), followed by labour management (1.28) and planning (1.19). It was also found that 49.17 per cent respondents showed medium extent of management of improved hybrid rice production technology, while 28.33 per cent respondents showed low extent of management of improved hybrid rice production technology and remaining 25.50 per cent showed high extent of management of improved hybrid rice production technology. The data indicate that the characteristics as education, size of land holding, farming experience, source of information, contract with extension agents, mass media exposure, innovativeness, economic motivation, risk orientation and decision making had significant relationship at 5 per cent level of significance with the management of improved hybrid rice cultivation practices.

How to cite this article : Nishad, Toran Lal, Birla, Antim, Singh, Sanjay, Singh, Shilpi and Khan, Azlan (2019). Management behaviour of the farmers in relation to improved cultivation of hybrid rice in Satna district (M.P.). Agric. Update, 14(1): 75-79; DOI : 10.15740/HAS/AU/14.1/75-79. Copyright@ 2019: Hind Agri-Horticultural Society. 